\title{
Change of plasma volume, osmolality, and acid-base status in healthy calves after feeding of milk and water- and milk-based oral rehydration solutions
}

\author{
L. Bachmann, ${ }^{\star 1}$ B. Schmidt, ${ }^{*}$ U. Rauwolf, $\dagger$ J. Wenge, ${ }^{*}$ and M. Coenen ${ }^{\star}$ \\ *Institute for Animal Nutrition, Nutrition Diseases and Dietetics, Faculty of Veterinary Medicine, Universität Leipzig, 04159 Leipzig, Germany \\ †Oberholz Farm for Teaching and Research of the Universität Leipzig, 04463 Großpösna, Germany
}

\section{ABSTRACT}

Oral rehydration solutions (ORS) are a simple and cheap method to treat diarrheal dehydration and acidosis. To maintain the energy supply of diarrheic calves, it is necessary to continue milk feeding. Suckling of milk or milk-based or hypertonic water-based ORS produces a slower rate of abomasal emptying than suckling isotonic water-based ORS. The faster abomasal passage of isotonic water-based ORS implies that efficacious electrolytes reach the gut more quickly, possibly providing a faster rate of rehydration. The aim of the study was to verify when and to what extent milk and water- and milk-based ORS increase plasma volume and affect plasma osmolality and acid-base status in healthy suckling calves. Eleven calves were fed with milk and with an ORS that was prepared in water or milk. Moreover, for one experiment, the calves remained fasting without suckling milk or ORS. During the experimental phase, the calves were deprived of water, hay, and concentrates. Blood samples were taken before and at various time points after feeding. Total plasma protein, osmolality, $\left[\mathrm{Na}^{+}\right],\left[\mathrm{K}^{+}\right],\left[\mathrm{Cl}^{-}\right]$, and albumin were determined. In 6 of 11 experiments, blood gas analysis was also performed. The calculated change in plasma volume after feeding was assessed from the plasma protein concentration before feeding $\left(\mathrm{P}_{\mathrm{t}=0}\right)$ and the plasma protein concentration after feeding $\left(\mathrm{P}_{\mathrm{t}=\mathrm{x}}\right):\left(\mathrm{P}_{\mathrm{t}=0}-\mathrm{P}_{\mathrm{t}=\mathrm{x}}\right) \times$ $100 / P_{t=x}$. Water- and milk-based ORS produced equal rates of plasma expansion in healthy calves. After milk feeding, the change in plasma volume was decelerated. Because of water influx, we did not observe a significant effect of feeding regimen on plasma osmolality. Acid-base status was little affected by feeding regimen. Feeding of milk-based ORS increased plasma strong ion difference, an alkaline response, which could potentially also reduce acidosis in calves suffering from diarrhea.

Key words: calf, oral rehydration, milk, strong ion difference

Received March 23, 2012.

Accepted June 7, 2012.

${ }^{1}$ Corresponding author: bachmann@vetmed.uni-leipzig.de

\section{INTRODUCTION}

Diarrhea is the most common cause of death in neonatal calves worldwide (USDA, 2007; Torsein et al., 2011; Azizzadeh et al., 2012). Diarrheic calves often suffer from dehydration and metabolic acidosis (Dalton et al., 1965; Hartmann et al., 1997). Treatment with oral rehydration solutions (ORS) is the usual therapy for diarrheic calves with a sufficient suckle reflex. Oral rehydration solutions provide a practical and inexpensive method to treat diarrheal imbalances of fluid and acid-base status. To maintain the energy supply of diarrheic calves, it is necessary to continue milk feeding (Garthwaite et al., 1994). Oral rehydration solutions are known to increase abomasal pH (Reinhold et al., 2006; Bachmann et al., 2009b) and, especially those containing $\mathrm{HCO}_{3}{ }^{-}$and citrate, prevent milk clotting in vitro (Naylor, 1992), thereby possibly inhibiting in vivo clotting of milk. This assumption resulted in the recommendation that feeding of milk and ORS should be strictly separated, which is a time-consuming therapy protocol and may be a reason why diarrheic calves are not adequately provided with ORS (see recommendations for oral rehydration management in diarrheic calves in Table 1; Rademacher et al., 2002). Recent studies have shown that ORS containing $\mathrm{HCO}_{3}{ }^{-}(\leq 62$ $\mathrm{mmol} / \mathrm{L})$ and citrate $(\leq 12 \mathrm{mmol} / \mathrm{L})$ do not interfere with milk clotting in vivo (Bachmann et al., 2009b; Constable et al., 2009). Given this knowledge on ORS not affecting abomasal milk clotting, the recommendation about separating electrolytes and milk might be obsolete, but suckling of milk or milk- or hypertonic water-based ORS produces slower rates of abomasal emptying than suckling an isotonic water-based ORS (Bell and Razig, 1973; Sen et al., 2006). The faster abomasal passage of isotonic water-based ORS implies that efficacious electrolytes reach the gut more quickly, possibly providing a faster rate of rehydration. The change of plasma volume after suckling has been assessed in a few studies (Levy et al., 1990; Nouri and Constable, 2006; Constable et al., 2009). At the 2-h time point, plasma expansion was equal after feeding milk replacer, water-based ORS, or milk replacer 
(MR)-based ORS (Bachmann et al., 2009b). No study exists to elucidate the time-course of change in plasma volume after suckling, which might confirm a faster plasma expansion of water-based ORS. However, a greater and more sustained increase in plasma volume could be detected after feeding MR-based or hypertonic ORS (Nouri and Constable, 2006; Bachmann et al., 2009b; Constable et al., 2009). Furthermore, in a study in calves with naturally acquired diarrhea, improved plasma volume expansion was found after feeding a hypertonic ORS (Sen et al., 2009).

To advance current recommendations about oral rehydration management of calves with diarrhea, the aim of the present study was to verify when and to what extent milk, water-based ORS, and milk-based ORS increase plasma volume and affect plasma osmolality and acid-base status in healthy suckling calves.

\section{MATERIALS AND METHODS}

Experiments were approved by federal authorities for animal research (Landesdirektion Leipzig, Germany) and conducted in accordance with the principles and specific guidelines presented in Guidelines for the Care and Use of Agricultural Animals in Research and Teaching (FASS, 2010).

\section{Animals}

Eleven healthy calves ( 7 male and 4 female) born at Oberholz (the farm for teaching and research of the Universität Leipzig, Germany) were used in the study. All calves were of Holstein-Friesian breed and their mean BW was $62.6 \pm 5.8 \mathrm{~kg}$. Calves were kept in calf boxes with straw bedding. Before the start of experiments and between the experimental days, calves were fed twice a day with cow milk ( $12 \%$ of BW). The calves had free access to water and were provided with hay and concentrates.

\section{Experimental Design}

Experiments started between d 3 and 15 after birth. Between experimental days, the calves had at least 2 $\mathrm{d}$ for recovery. The mean age of calves in all experiments was $12 \pm 5 \mathrm{~d}$. The experimental period per day consisted of $4 \mathrm{~h}$ (0800 to $1200 \mathrm{~h}$ ). Before the onset of the experiments, each calf was fitted with an indwelling catheter in the jugular vein and a blood sample was taken 5 min before feeding. Catheters were secured in place with suture material. Every calf underwent 4 experimental phases: milk feeding, feeding of waterbased ORS (water-ORS), feeding of milk-based ORS
Table 1. Recommendations for oral rehydration management in diarrheic calves (Rademacher et al., 2002)

\begin{tabular}{ll}
\hline Time of day & Feeding regimen \\
\hline Morning & $1.5-2 \mathrm{~L}$ of milk \\
$>2$ h later & $1-1.5 \mathrm{~L}$ of water-based ORS \\
Midday & $1.5-2 \mathrm{~L}$ of milk \\
$>2$ h later & $1-1.5 \mathrm{~L}$ of water-based ORS \\
Evening & $1.5-2$ L of milk \\
Night & $1-2 \mathrm{~L}$ of water-based ORS \\
\hline
\end{tabular}

${ }^{1}$ Oral rehydration solution.

(milk-ORS), and fasting. For the experiments, the calves received $2 \mathrm{~L}$ of milk, water-ORS, or milk-ORS at $0800 \mathrm{~h}$ or remained fasting, respectively, and were deprived of water, hay, and concentrates. Blood samples were taken via jugular catheter at $5,15,25,35,45$ min and $1,1.25,1.5,2,3$, and $4 \mathrm{~h}$ after feeding or the start of the experimental period. At the end of the experimental period, vein catheters were removed and calves were fed with $2 \mathrm{~L}$ of milk and had free access to water, hay, and concentrate. Osmolality, $\mathrm{pH},\left[\mathrm{Na}^{+}\right]$, $\left[\mathrm{K}^{+}\right],\left[\mathrm{Cl}^{-}\right]$and strong ion difference $\left(\left[\mathbf{S I D}_{3}\right]:\left[\mathrm{Na}^{+}\right]+\right.$ $\left.\left[\mathrm{K}^{+}\right]-\left[\mathrm{Cl}^{-}\right]\right)$in the different feeding regimens were determined or calculated according to the specifications of the manufacturer of the ORS, respectively (Table 2). Lytafit (Albrecht GmbH, Aulendorf, Germany), the commercial product used in the study, is an ORS with a $\mathrm{HCO}_{3}{ }^{-}$concentration of $62 \mathrm{mmol} / \mathrm{L}$. Additional ingredients are lactose, glycine, $\mathrm{Ca}^{2+}$, and $\mathrm{Mg}^{2+}$. According to the manufacturer's recommendations, Lytafit should only be prepared in water. Lytafit was also used in the study of Bachmann et al. (2009b), in which it was shown that the preparation of Lytafit in MR did not impair abomasal milk clotting.

\section{Measurements and Analyses}

All 528 samples were analyzed for total plasma protein (Hitachi 912, Boehringer, Mannheim, Germany; biuret method) and osmolality (Osmometer K-7400, Knauer, Berlin, Germany; freezing point depression method). Concentrations of $\mathrm{Na}^{+}, \mathrm{K}^{+}, \mathrm{Cl}^{-}$(by ion selective electrode), and albumin (by bromocresol green assay) in plasma were determined 5 min before, $35 \mathrm{~min}$, and $1,1.5,2$, and $4 \mathrm{~h}$ after feeding (in total, 264 samples). In 24 (6 of 11 calves) of the 44 experiments, blood gas analysis (ABL 80 Flex, Radiometer, Copenhagen, Denmark) was performed directly after blood sampling at $5 \mathrm{~min}$ before, $35 \mathrm{~min}, 1,1.5,2$, and $4 \mathrm{~h}$ after feeding. Plasma and feed samples were frozen $\left(-20^{\circ} \mathrm{C}\right)$ until measurement of protein, albumin, osmolality, and electrolytes. Osmolality and $\mathrm{pH}$ were determined in milk and ORS, and measurement of $\left[\mathrm{Na}^{+}\right]$, 
Table 2. Composition of feeding regimen: osmolality, $\left[\mathrm{Na}^{+}\right],\left[\mathrm{K}^{+}\right],\left[\mathrm{Cl}^{-}\right]$and strong ion difference $\left(\left[\mathrm{SID}_{3}\right]=\right.$ $\left.\left[\mathrm{Na}^{+}\right]+\left[\mathrm{K}^{+}\right]-\left[\mathrm{Cl}^{-}\right]\right)$of milk, water-based oral rehydration solution (ORS), and milk-based ORS

\begin{tabular}{lccccc}
\hline $\begin{array}{l}\text { Feeding } \\
\text { regimen }\end{array}$ & $\begin{array}{c}\text { Osmolality } \\
(\mathrm{mOsm} / \mathrm{L})\end{array}$ & $\begin{array}{c}{\left[\mathrm{Na}^{+}\right]} \\
(\mathrm{mmol} / \mathrm{L})\end{array}$ & $\begin{array}{c}{\left[\mathrm{K}^{+}\right]} \\
(\mathrm{mmol} / \mathrm{L})\end{array}$ & $\begin{array}{c}{\left[\mathrm{Cl}{ }^{-}\right]} \\
(\mathrm{mmol} / \mathrm{L})\end{array}$ & $\begin{array}{c}{\left[\mathrm{SID}_{3}\right]} \\
(\mathrm{mmol} / \mathrm{L})\end{array}$ \\
\hline Milk & 290 & 25 & 40 & 30 & 35 \\
Water-ORS & 365 & 81 & 13 & 45 & 49 \\
Milk-ORS & 655 & 106 & 53 & 75 & 84 \\
\hline
\end{tabular}

$\left[\mathrm{K}^{+}\right]$and $\left[\mathrm{Cl}^{-}\right]$was conducted in milk. The manufacturer's data on electrolyte concentrations in the ORS product were used for water-ORS and milk-ORS. The calculated change in plasma volume after feeding was assessed from the plasma protein concentration before feeding $\left(\mathbf{P}_{\mathbf{t}=\mathbf{0}}\right)$ and the plasma protein concentration after feeding $\left(\mathbf{P}_{\mathrm{t}=\mathrm{x}}\right):\left(\mathrm{P}_{\mathrm{t}=0}-\mathrm{P}_{\mathrm{t}=\mathrm{x}}\right) \times 100 / \mathrm{P}_{\mathrm{t}=\mathrm{x}}(\operatorname{van}$ Beaumont et al., 1972).

Based on the concentrations of the electrolytes and albumin in plasma, $\left[\mathrm{SID}_{3}\right]$ and acid total $\left(\left[\mathbf{A}_{\text {tot }}\right]=0.622\right.$ $\times$ [albumin]) were calculated (Constable et al., 2005).

\section{Statistical Analyses}

Data were expressed as mean ( \pm standard deviation) and analyzed by using repeated-measures ANOVA. For the parameters that offered statistically significant effects of time and feeding regimen or statistically significant interactions between time and feeding regimen, respectively, the least significant difference (LSD) test was computed to detect differences within or between the feeding regimens. Pearson product-moment correlation coefficients $(\mathrm{r})$ were calculated between partial pressure of $\mathrm{CO}_{2}\left(\mathbf{p C O}_{2}\right)$, $\left[\mathrm{SID}_{3}\right],\left[\mathrm{A}_{\text {tot }}\right]$ and $\mathrm{pH}$ in blood. For statistical analysis, the software Statistica (version 7, StatSoft GmbH, Hamburg, Germany) was used.

\section{RESULTS}

\section{Change in Plasma Volume and Plasma Total Protein}

During the fasting period, plasma volume varied to some extent and significant differences to baseline values could be detected $(P<0.01)$ at the 2 -h time point. The rate of plasma expansion was similar after feeding water- or milk-based ORS. No deceleration of change in plasma volume after feeding ORS prepared in milk could be observed: plasma volume increased significantly compared with baseline values $(P<0.01) 15 \mathrm{~min}$ after administration of water-ORS or milk-ORS. Three hours after water- and milk-ORS feeding, as well as 1.5 $\mathrm{h}$ after water-ORS feeding and $4 \mathrm{~h}$ after milk-ORS feeding, the values of plasma volume were also significantly different from fasting conditions $(P<0.05)$. After milk feeding, the change in plasma volume was delayed; an expansion in plasma volume was detected 25 min after suckling $(P<0.01)$. Compared with those under fasting conditions, the values after milk feeding were not significantly different. Plasma volume was significantly reduced $3 \mathrm{~h}$ after milk feeding compared with that after feeding of milk-ORS $(P<0.05)$. However, compared with baseline, feeding of both ORS and milk increased the plasma volume until $4 \mathrm{~h}$ after suckling (Figure 1).

Corresponding to changes in plasma volume, the feeding of milk, water-ORS, or milk-ORS produced decreases in plasma total protein concentration. Plasma total protein was significantly diminished after $15 \mathrm{~min}$ of feeding water-ORS and milk-ORS, whereas a significant decrease of plasma total protein occurred $25 \mathrm{~min}$ $(P<0.01)$ after feeding of milk (Figure 2$)$.

\section{Osmolality}

In contrast to changes in plasma volume and plasma total protein, plasma osmolality was not affected by feeding regimen. Plasma osmolality remained constant, and no significant effects of time or feeding regimen could be detected (Figure 3).

\section{Acid-Base Status}

A statistically significant increase in $\mathrm{pH}$ could be determined $4 \mathrm{~h}$ after feeding of water-ORS and milkORS, but an increase in $\mathrm{pH}$ was also observed after $4 \mathrm{~h}$ of fasting. Two hours after feeding of milk-ORS, $\left[\mathrm{SID}_{3}\right]$ in plasma increased significantly, whereas the $\left[\mathrm{SID}_{3}\right]$ values after milk feeding declined significantly.

Every fluid meal caused a decrease in plasma $\left[\mathrm{A}_{\text {tot }}\right]$ from 35 min after feeding until the end of the observation period. Analogous to the increase in plasma volume and decrease of total protein concentration, $\left[\mathrm{A}_{\text {tot }}\right]$ in plasma was diminished after $2 \mathrm{~h}$ of fasting.

No significant effects of feeding regimen on $\mathrm{pCO}_{2}$ could be detected (Table 3), but significant correlations between $\mathrm{pCO}_{2}$ and venous $\mathrm{pH}$ were observed $(\mathrm{r}=$ $-0.62, P<0.01 ;$ Figure 4$)$. A weak correlation between plasma $\left[\mathrm{SID}_{3}\right]$ and $\mathrm{pH}$ was also found $(\mathrm{r}=0.27, P<$ 0.01 ; Figure 5$)$. Plasma $\left[A_{\text {tot }}\right]$ did not correlate with venous $\mathrm{pH}$. 


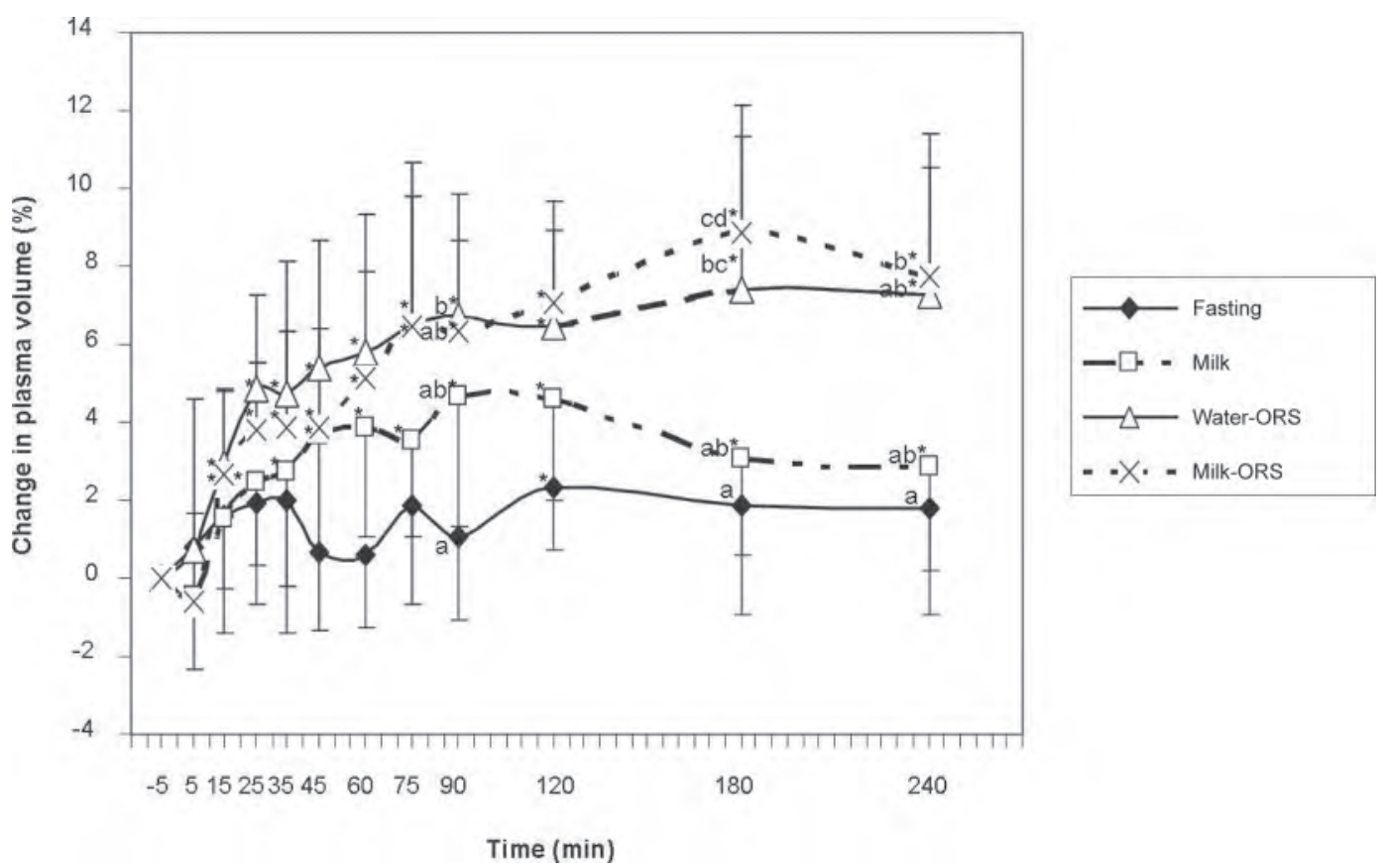

Figure 1. Calculated change in plasma volume (arithmetic mean \pm SD) in 44 experiments. Asterisks $(*)$ indicate statistically significant differences from baseline $(P<0.01)$. Lowercase letters indicate statistically significant differences between feeding of milk, water-based oral rehydration solution (water-ORS), or milk-based oral rehydration solution (milk-ORS) and fasting conditions (fasting), respectively $(P<0.05)$.

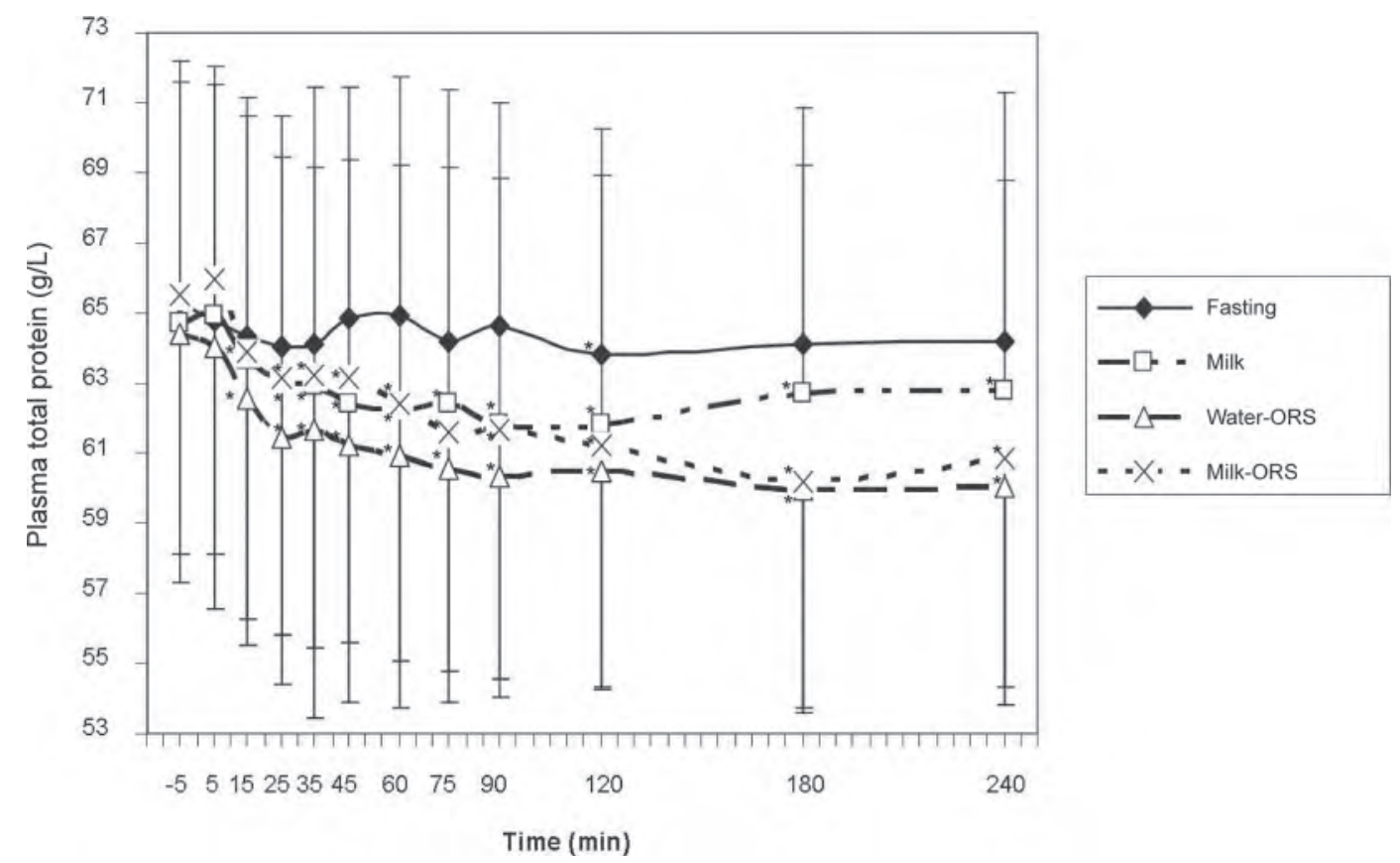

Figure 2. Total protein concentration in plasma (arithmetic mean \pm SD) during a 4-h fasting period (fasting) and after feeding of milk, water-based oral rehydration solution (water-ORS), and milk-based oral rehydration solution (milk-ORS). Asterisks $(*)$ indicate statistically significant differences compared with the time $=-5$ min value $(P<0.01)$. 


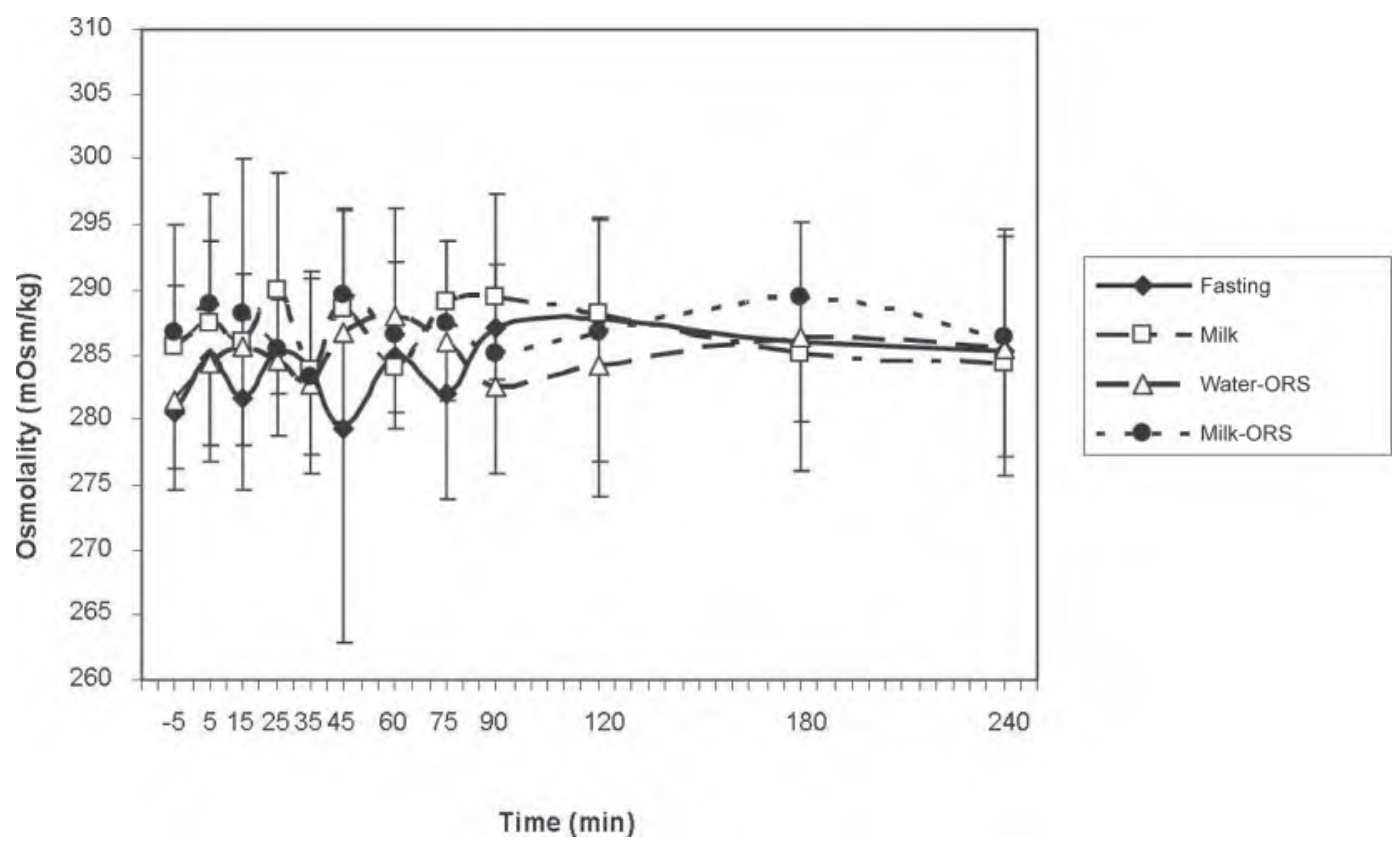

Figure 3. Plasma osmolality (arithmetic mean $\pm \mathrm{SD}$ ) during a 4-h fasting period (fasting) and after feeding of milk or water- or milk-based oral rehydration solution (water-ORS, milk-ORS), respectively.

\section{DISCUSSION}

The volume and caloric content of a fluid meal are the most important determinants of abomasal empty- ing rate in suckling calves (Ash, 1964; Hunt and Stubbs, 1975). Isotonic, caloric-inert solutions such as $\mathrm{NaHCO}_{3}$ pass the abomasum quickly in an exponential manner. In contrast, isotonic caloric solutions such as isotonic

Table 3. Values (means $\pm \mathrm{SD}$ ) of venous $\mathrm{pH}$, strong ion difference $\left(\left[\mathrm{SID}_{3}\right]\right)$, acid total $\left(\left[\mathrm{A}_{\mathrm{tot}}\right]\right)$, and partial pressure of $\mathrm{CO}_{2}$ (pCO $\mathrm{p}_{2}$ ) of the fasting period and before feeding and $35 \mathrm{~min}, 1,1.5,2$, and $4 \mathrm{~h}$ after feeding of milk, water-based oral rehydration solution (water-ORS), and milkbased ORS (milk-ORS)

\begin{tabular}{lccccc}
\hline & \multicolumn{5}{c}{ Time relative to feeding } \\
Treatment and \\
parameter
\end{tabular}

${ }^{1}\left[\mathrm{SID}_{3}\right]=\left[\mathrm{Na}^{+}\right]+\left[\mathrm{K}^{+}\right]-\left[\mathrm{Cl}^{-}\right] ;\left[\mathrm{A}_{\text {tot }}\right]=0.622 \times[$ Albumin $] . \mathrm{pH}$ and $\mathrm{pCO}_{2}$ were measured in 6 of 11 calves; [SID $\left.{ }_{3}\right]$ and $\left[\mathrm{A}_{\text {tot }}\right]$ were measured in all 11 calves.

${ }^{*} P<0.01$ compared with values before feeding. 


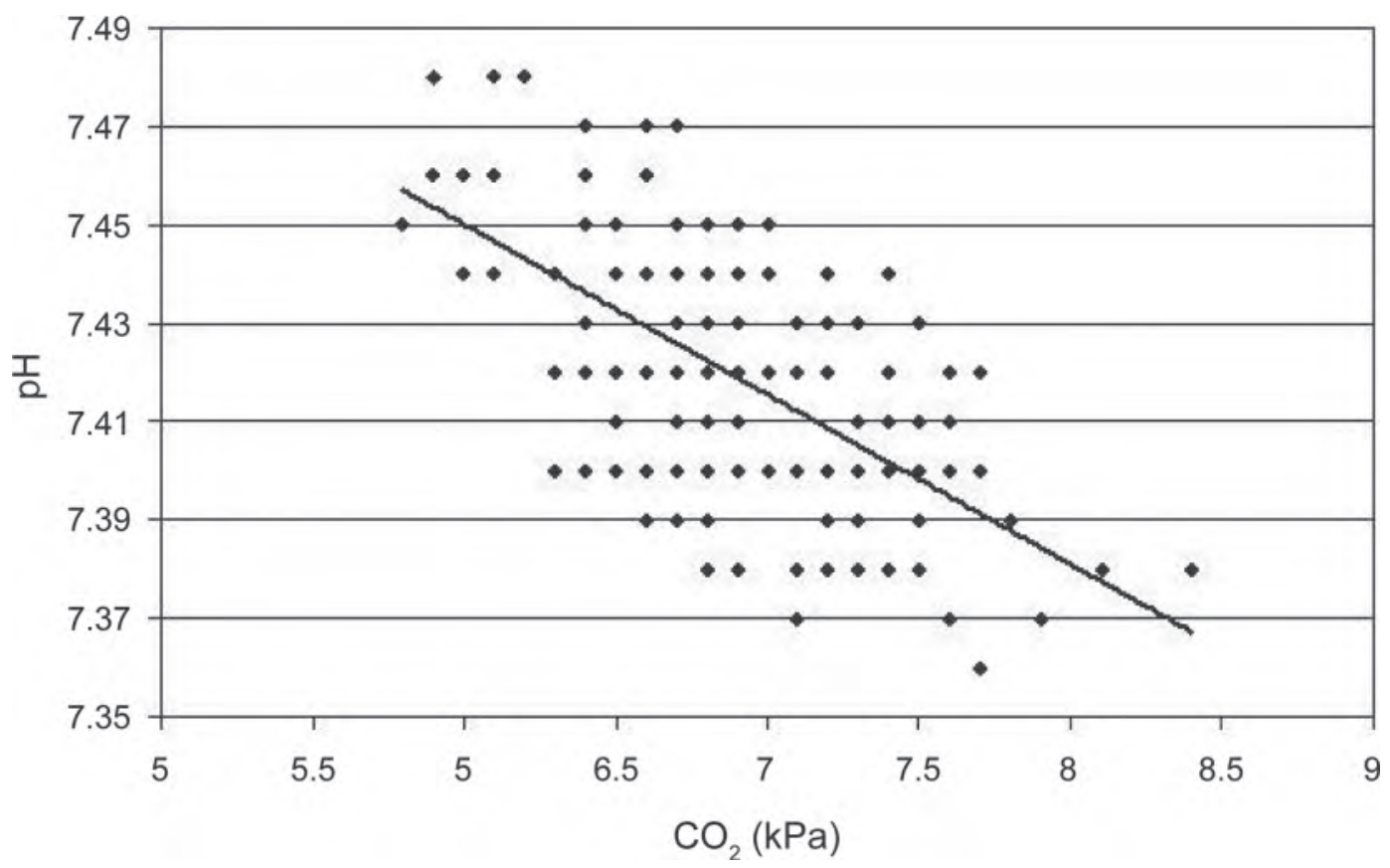

Figure 4. Scatterplot of the correlation between partial pressure of $\mathrm{CO}_{2}\left(\mathrm{pCO}_{2}\right)$ and $\mathrm{pH}$ in plasma: $\mathrm{pCO}_{2}$ and pH were negatively correlated $(\mathrm{r}=-0.62)$. Solid line $=$ line of regression.

glucose, milk, or MR are emptied more slowly in a linear manner, in order that nutrients reach the gut in a constant rate (Bell and Razig, 1973). Other factors that influence abomasal passage are type of protein and fat, pH in the duodenum, and osmolality (Bell et al., 1981).
Hypertonic ORS delay abomasal emptying (Nouri and Constable, 2006).

When feeding milk or MR, abomasal curd formation is responsible for the prolonged duration of caseins in the abomasum, and curd regulates the flow of fat

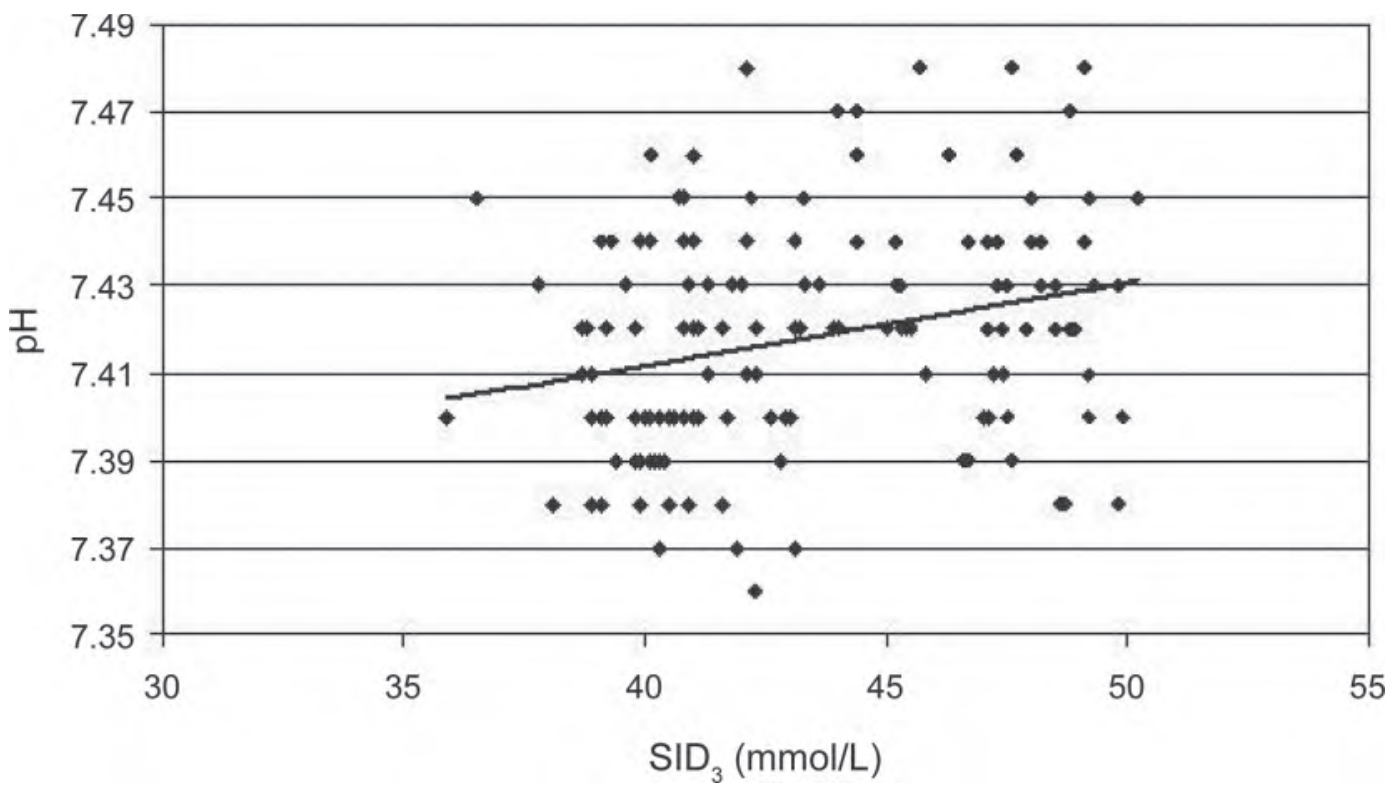

Figure 5. Correlation between strong ion difference $\left(\left[\mathrm{SID}_{3}\right]=\left[\mathrm{Na}^{+}\right]+\left[\mathrm{K}^{+}\right]-\left[\mathrm{Cl}^{-}\right]\right.$and $\mathrm{pH}$ in plasma. Scatterplot of the relationship between $\left[\mathrm{SID}_{3}\right]$ and $\mathrm{pH}$ in the plasma samples: $\left[\mathrm{SID}_{3}\right]$ and $\mathrm{pH}$ were positively correlated $(\mathrm{r}=0.27)$. Solid line $=$ line of regression. 
and protein in the small intestine. Lactose and whey are rapidly expelled from the abomasum and released to the duodenum (Petit et al., 1987). The duodenal receptors modulate stomach emptying of digesta. The hydrogen ion mass appears to activate the release of somatostatin, which may be associated with the inhibition of gastric motility (Sissons et al., 1988). Adding ORS to milk or MR may influence the release of whey into the small intestine and therefore the rate of rehydration.

Plasma volume increases after a fluid meal (Levy et al., 1990; Nouri and Constable, 2006; Bachmann et al., 2009b; Constable et al., 2009). In the study of Nouri and Constable (2006), a low-glucose (= isotonic) ORS provided a faster rate of plasma expansion than a highglucose (= hypertonic) ORS. However, high-glucose ORS produced a larger and more sustained increase in plasma volume. According to Constable et al. (2009), the speed of plasma expansion does not differ whether feeding milk or milk-based ORS. The addition of electrolytes to cow milk or MR led to greater expansion of plasma volume in healthy calves (Bachmann et al., 2009b; Constable et al., 2009). After administration of a hypertonic solution, a decrease in plasma volume could be determined in calves with diarrhea and dehydration (Jones et al., 1984) but not in healthy calves (Levy et al., 1990).

Several studies indicate that calves should not be starved from milk (Radostits et al., 1975; Garthwaite et al., 1994) and that calves should be provided with an ORS, because ORS reduce dehydration and metabolic acidosis in diarrheic calves (Constable et al., 2001). However, no study has shown whether the chronological order in which diarrheic calves are administered milk, water-based ORS, or milk-based ORS matters.

We hypothesized that the faster abomasal passage of water-based ORS would produce a faster rate of rehydration in diarrheic calves; therefore, diarrheic calves would recover faster if they were given a waterbased ORS immediately after presentation of diarrheal symptoms. The results of the present study contradict this hypothesis. Hypertonic water-based solutions, milk-based solutions, or MR-based solutions may pass the abomasum more slowly than water-based isotonic solutions, but the rate of plasma expansion is driven particularly by the absorption of sodium and glucose (Constable et al., 2009). In the current study, $\left[\mathrm{Na}^{+}\right]$was almost 2-fold higher in milk-ORS than in water-ORS (Table 2). Hence, the delivery of sodium into the duodenum and the absorption of sodium via the duodenal mucosa might be the same per unit time, even though abomasal passage of milk-ORS is slower compared with water-ORS. The slower rate of plasma expansion after milk feeding might be due to lower sodium and higher energy contents and to time at which the separation of curd and whey occurs, respectively. Preparing ORS in milk or MR might be an effective method to treat diarrheal dehydration and acidosis. However, the results of plasma expansion after suckling have to be confirmed in calves suffering from diarrheal dehydration.

Diarrhea occurs following negative sodium and potassium balance and a decrease in extracellular fluid volume (Dalton et al., 1965). Diarrheic calves are isotonically or hypotonically dehydrated (Fayet, 1971; Hartmann et al., 1983). In diarrhea, the kidneys are able to compensate for fecal water and electrolyte losses (Fisher and Delafuente, 1972). Because of renal failure, calves dying from diarrhea develop hypertonic dehydration (Hartmann et al., 1983). In the present study, we found no significant effect of hypertonic milk-ORS on plasma osmolality. However, water influx into plasma space did occur, which resulted in extended plasma volume and adjusted plasma osmolality. In healthy calves, mean total body water is not impaired and water might be distributed to the plasma space to maintain plasma osmolality. In diarrheic calves, mean total body water is reduced, with the plasma volume being most decreased (Thornton and English, 1978). Administration of hypertonic ORS might increase plasma osmolality in calves with diarrhea; in turn, brain osmoreceptors are dehydrated and thirst is triggered (Thornton, 2010).

Increases in plasma sodium concentration may result in neurological signs associated with acute hypernatremia, such as lethargy, weakness, depression, seizures, coma, and death (Lofstedt and Collatos, 1997). Thus, water should be freely available for diarrheic calves, especially for those receiving hypertonic or milk-based ORS. This requirement is supported by the study of Fisher and Martinez (1976), in which plasma volume in diarrheic calves was directly related to milk intake and not to fecal output. Furthermore, in the study of Sen et al. (2009), calves receiving a hypertonic ORS developed a significantly increased plasma volume after they had free access to water.

In Germany, regulations require that calves have free access to water after 2 wk of life (TierSchNutztV, 2006). However, neonatal diarrhea occurs predominantly during the first $4 \mathrm{wk}$ of life (Azizzadeh et al., 2012). Therefore, it is necessary to change legislation in every country that negates the water requirements of neonatal calves. Furthermore, calves should be familiarized with water intake before they develop symptoms of diarrhea.

The acid-base status of animals can be evaluated by the Henderson-Hasselbalch equation or the Stewart model of acid-base physiology. According to Stewart (1981), acid-base status involves 3 independent variables: (1) strong ion difference, (2) $\mathrm{A}_{\mathrm{tot}}$, and (3) $\mathrm{pCO}_{2}$. The traditional parameters of healthy calves were little 
affected by administration of ORS or milk. Although we observed a significant increase in blood $4 \mathrm{~h}$ after ORS feeding, it cannot be seen as an effect of feeding regimen because we also observed an increase in venous $\mathrm{pH}$ after $4 \mathrm{~h}$ of fasting.

The $\mathrm{pCO}_{2}$ did not change significantly, but we did find a significant negative correlation between $\mathrm{pCO}_{2}$ and $\mathrm{pH}$ in blood, indicating a strong relationship between respiration and acid-base status in healthy calves. In the present study, $\left[\mathrm{SID}_{3}\right]$ also correlated weakly with venous blood $\mathrm{pH}$ in healthy calves, suggesting an influence of plasma electrolytes on acid-base physiology. This relationship between $\mathrm{pH}$ and SID supports the findings of Constable et al. (2005). Diarrheic calves suffer from strong ion acidosis; for example, hyperchloremia or Dlactate acidosis, which results in a reduction of [SID] (Constable et al., 2005; Bachmann et al., 2009a). A successful treatment of diarrheic calves is associated with an increase of [SID]. Thus, ORS with $\left[\mathrm{SID}_{3}\right]$ values $>80 \mathrm{mmol} / \mathrm{L}$, which expand [SID] in healthy calves, should be used in oral rehydration treatment of diarrheic calves (Constable et al., 2005; Bachmann et al., 2009a,b).

Furthermore, because of dehydration, $\left[\mathrm{A}_{\text {tot }}\right]$ is increased in calves with diarrhea (Constable et al., 2005; Bachmann et al., 2009a), which can be corrected by expansion of plasma volume. An increase of plasma volume could be achieved by feeding milk, MR, or ORS (Bachmann et al., 2009b; Constable et al., 2009). Feeding hypertonic or ORS prepared in milk or MR seems to be more effective in correcting fluid homeostasis because a greater and more sustained increase in plasma volume could be detected after feeding these solutions (Nouri and Constable, 2006; Bachmann et al., 2009b; Constable et al., 2009). In other words, because of a low sodium concentration, plasma volume expansion is reduced after feeding of milk or hypotonic water-based ORS. The total sodium intake determines the change in plasma volume.

\section{CONCLUSIONS}

Water- or milk-based ORS produce equal rates of plasma volume expansion in healthy calves. Preparing ORS in milk or MR might be an easy way to provide diarrheic calves with electrolytes and buffering substances. When hypertonic solutions such as milkbased ORS are fed, water should be freely available for diarrheic calves; otherwise, a sodium imbalance might result. In this study, ORS with a $\left[\mathrm{SID}_{3}\right]$ of $84 \mathrm{mmol} / \mathrm{L}$ increased plasma $\left[\mathrm{SID}_{3}\right]$ in healthy calves, indicating that, for effective correction of metabolic acidosis in diarrheic calves, ORS should contain high $\left[\mathrm{SID}_{3}\right]$ values.

\section{ACKNOWLEDGMENTS}

This project was financially supported by DFG (Bonn, Germany). The authors thank Austin Bell (Banfield Pet Hospital, Denver, CO) for linguistic revision of the manuscript and all students of veterinary medicine in Universität Leipzig (Leipzig, Germany) who were involved in the conduct of the experiments.

\section{REFERENCES}

Ash, R. W. 1964. Abomasal secretion and emptying in suckled calves. J. Physiol. 172:425-438.

Azizzadeh, M., H. F. Shooroki, A. S. Kamalabadi, and M. A. Stevenson. 2012. Factors affecting calf mortality in Iranian Holstein dairy herds. Prev. Vet. Med. 104:335-340.

Bachmann, L., J. Berchtold, C. Siegling-Vlitakis, A. Willing, E. Radtke, and H. Hartmann. 2009a. Stewart variables of the acidbase status in calves. Age related behaviour and influence of spontaneously occurring diarrhoea. Tierarztl. Prax. Ausg. G Grosstiere Nutztiere 37:365-374.

Bachmann, L., T. Homeier, S. Arlt, M. Brueckner, H. Rawel, C. Deiner, and H. Hartmann. 2009b. Influence of different oral rehydration solutions on abomasal conditions and the acid-base status of suckling calves. J. Dairy Sci. 92:1649-1659.

Bell, F. R., M. Nouri, and D. E. Webber. 1981. The interplay between hydrogen ions, bicarbonate ions and osmolality in the anterior duodenum modulating gastric function in the conscious calf. J. Physiol. 314:331-341.

Bell, F. R., and S. A. Razig. 1973. Gastric emptying and secretion in the milk-fed calf. J. Physiol. 228:499-512.

Constable, P. D., W. Grunberg, and L. Carstensen. 2009. Comparative effects of two oral rehydration solutions on milk clotting, abomasal luminal $\mathrm{pH}$, and abomasal emptying rate in suckling calves. J. Dairy Sci. 92:296-312.

Constable, P. D., H. R. Stampfli, H. Navetat, J. Berchtold, and F. Schelcher. 2005. Use of a quantitative strong ion approach to determine the mechanism for acid-base abnormalities in sick calves with or without diarrhea. J. Vet. Intern. Med. 19:581-589.

Constable, P. D., E. Thomas, and B. Boisrame. 2001. Comparison of two oral electrolyte solutions for the treatment of dehydrated calves with experimentally-induced diarrhoea. Vet. J. 162:129 141

Dalton, R. G., E. W. Fisher, and W. I. Mcintyre. 1965. Changes in blood chemistry body weight and haematocrit of calves affected with neonatal diarrhoea. Br. Vet. J. 121:34.

FASS. 2010. Guide for the Care and Use of Agricultural Animals in Research and Teaching. 3rd ed. Federation of Animal Science Societies. 3rd ed. FASS, Champaign, IL.

Fayet, J. C. 1971. Plasma and faecal osmolality, water kinetics and body fluid compartments in neonatal calves with diarrhoea. Br. Vet. J. 127:37.

Fisher, E. W., and G. Delafuente. 1972. Water and electrolyte studies in newborn calves with particular reference to effects of diarrhea. Res. Vet. Sci. 13:315-322.

Fisher, E. W., and A. A. Martinez. 1976. Aspects of body-fluid dynamics of neonatal calf diarrhea. Res. Vet. Sci. 20:302-305.

Garthwaite, B. D., J. K. Drackley, G. C. McCoy, and E. H. Jaster. 1994. Whole milk and oral rehydration solution for calves with diarrhea of spontaneous origin. J. Dairy Sci. 77:835-843.

Hartmann, H., J. Berchtold, and W. Hofmann. 1997. Pathophysiological aspects of acidosis in diarrhoeic calves. Tierarztl. Umsch. 52:568-574.

Hartmann, H., H. Meyer, G. Steinbach, N. Rossow, and R. Lesche. 1983. Effects of diarrhea on electrolyte level and osmolality in calf blood. Monatsh. Veterinarmed. 38:292-296. 
Hunt, J. N., and D. F. Stubbs. 1975. The volume and energy content of meals as determinants of gastric emptying. J. Physiol. 245:209-225.

Jones, R., R. W. Phillips, and J. L. Cleek. 1984. Hyperosmotic oral replacement fluid for diarrheic calves. J. Am. Vet. Med. Assoc. 184:1501-1505.

Levy, M., A. M. Merritt, and L. C. Levy. 1990. Comparison of the effects of an isosmolar and hyperosmolar oral rehydrating solution on the hydration status, glycemia and ileal content composition of healthy neonatal calves. Cornell Vet. 80:143-151.

Lofstedt, J., and C. Collatos. 1997. Disorders of sodium balance in diarrheic calves: Pathophysiology and treatment. Compend. Contin. Educ. Pract. Vet. 19:S134.

Naylor, J. M. 1992. Effects of electrolyte solutions for oral administration on clotting of milk. J. Am. Vet. Med. Assoc. 201:1026-1029.

Nouri, M., and P. D. Constable. 2006. Comparison of two oral electrolyte solutions and route of administration on the abomasa emptying rate of Holstein-Friesian calves. J. Vet. Intern. Med. 20:620-626.

Petit, H. V., M. Ivan, and G. J. Brisson. 1987. Duodenal flow of digesta in preruminant calves fed clotting or nonclotting milk replacer. J. Dairy Sci. 70:2570-2576.

Rademacher, G., I. Lorenz, and W. Klee. 2002. Tränkung und Behandlung von Kälbern mit Neugeborenendurchfall. Tierarztl. Umsch. $57: 177-189$.

Radostits, O. M., C. S. Rhodes, M. E. Mitchell, T. P. Spotswood, and M. S. Wenkoff. 1975. A clinical evaluation of antimicrobial agents and temporary starvation in the treatment of acute undifferentiated diarrhea in newborn calves. Can. Vet. J. 16:219-227.

Reinhold, S., B.-W. Hertsch, S. Höppner, W. Heuwieser, and H. Hartmann. 2006. Wirkung von Milch und Diättränken mit und ohne Bikarbonationen auf den intraluminalen pH-Wert im Labmagen und den systemischen Säuren-Basen-Status beim Kalb. Tierarztl. Prax. Ausg. G Grosstiere Nutztiere 34:368-376.
Sen, I., V. Altunok, M. Ok, A. Coskun, and P. D. Constable. 2009. Efficacy of oral rehydration therapy solutions containing sodium bicarbonate or sodium acetate for treatment of calves with naturally acquired diarrhea, moderate dehydration and strong ion acidosis. J. Am. Vet. Med. Assoc. 234:926-934.

Sen, I., P. D. Constable, and T. S. Marshall. 2006. Effect of suckling isotonic or hypertonic solutions of sodium bicarbonate or glucose on abomasal emptying rate in calves. Am. J. Vet. Res. 67:13771384.

Sissons, J. W., F. R. Bell, C. L. Girard, and J. A. Wass. 1988. Nutrient sensitivity of gastric emptying of digesta in the preruminant calf. Br. J. Nutr. 59:335-343.

Stewart, P. A. 1981. How to Understand Acid-Base. 1st ed. Elsevier North Holland Inc., New York, NY.

Thornton, J. R., and P. B. English. 1978. Body water of calves: Change in distribution with diarrhoea. Br. Vet. J. 134:445-453.

Thornton, S. N. 2010. Thirst and hydration: Physiology and consequences of dysfunction. Physiol. Behav. 100:15-21.

TierSchNutztV (Tierschutz-Nutztierhaltungsverordnung). 2006. Regulation on the protection of livestock and other animals kept for the production animal products in their attitude. $\S 11$ : Monitoring, Caring and Feeding of Calves. Bundesjustizministerium Germany, Berlin, Germany.

Torsein, M., A. Lindberg, C. H. Sandgren, K. P. Waller, M. Tornquist, and C. Svensson. 2011. Risk factors for calf mortality in large Swedish dairy herds. Prev. Vet. Med. 99:136-147.

US Department of Agriculture. 2007. Dairy 2007 Part II: Changes in the U.S. Dairy Cattle Industry, 1991-2007. National Animal Health Monitoring System, Animal and Plant Health Inspection Service, Fort Collins, CO.

van Beaumont, W., J. E. Greenleaf, and L. Juhos. 1972. Disproportional changes in hematocrit, plasma volume, and proteins during exercise and bed rest. J. Appl. Physiol. 33:55-61. 